\title{
Globalisation of the Tourism Industry: Future Trends and Challenges for South Africa
}

\section{E Heath}

\section{Department of Tourism Management, University of Pretoria}

\begin{abstract}
The pressure of globalisation is having a major impact on tourism destinations throughout the world. The implications for destination marketers are profound and the response will require a new strategic focus and approach. This paper focuses on the changing global tourism environment, with particular emphasis on the key trends and developments that are likely to occur in the early part of the twenty first century. The paper concludes with an outline of the key factors that need to be addressed to ensure competitive success for developing tourism destinations such as South Africa.
\end{abstract}

JEL O 10

\section{INTRODUCTION}

Attempting to understand and interpret the impact of globalisation and the future of tourism is very much like peering into a crystal ball. It may not be possible to bring the future into a clearly focused picture, but the powerful light of a dynamic and ever-changing industry is glowing at the core of the crystal bail.

The one feature that will increasingly distinguish the "new" tourism from the "old" tourism is the fact that not only will rapid globalisation and change be increasingly evident, but it will be accepted as inevitable and therefore tourism organisations will need to manage change. In this paper, the changing global tourism environment is explored with particular emphasis on the key trends and developments that are likely to occur in the early part of the twenty first century. Particular emphasis will be placed on the possible implications of these trends to the tourism industry in Southem Africa.

All indications are that in the first decades of this century there will be certain predominant global drivers of change. Whereas in the mid-nineteenth century and the early decades of the twentieth century transport developments were key drivers of tourism change, major technological advances and the maturing of the tourism marketplace have characterised changes in the tourism industry since the mid-nineties. This suggests that some of these variables are already evident, 
appropriately states, "To cope with future tourism planning, management and research, tourism professionals should be Renaissance men and women". This statement is particularly relevant to the Southern African tourism industry, which has abundant tourism potential, but is also faced with major challenges. To optimise the tourism potential of the sub-continent, tourism professionals will increasingly have to innovatively and pro-actively imagine, anticipate and gauge the future as a basis for future planning, development and management of the tourism industry.

\section{GLOBALISATION AS A MEGATREND OF STRATEGIC IMPORTANCE TO TOURISM}

As the concept of a "Global Village" increasingly becomes a reality, mainly as a result of technological advancement in transportation and communications, the world faces several questions of sustenance, peace, economy, stability and survival. Globalisation of tourism is indeed one of the many factors responsible for the above. It has been described as a "megatrend", which is associated with different dimensions and consequences - both positive and negative (Adejuwon, 1996).

In a generic tourism sense, globalisation comprises three basic elements. First, there is the geographical side. The term covers intraregional and interregional travel, and the extension of tourism to a worldwide scale. Second, globalisation can be seen in terms of convergence in world tastes, product preferences, and life styles, which leads to growing standardisation and market homogenisation (a trend towards similar customer preferences worldwide). A third basic element is the existence of internationally similar practices around the world, such as distribution systems, marketing practices, product development, etc. The first and second characteristic is more demand orientated, while the third is supply orientated (Vanhove, 1996).

The globalisation of the tourism industry has several significant strategic implications. It increases competitive pressures by bringing more entrants into the market. It increases the complexity of doing business, from learning to find and manage employees with a diverse background in the different countries to designing and delivering products uniquely suited for special interest travel markets. It also requires a new knowledge base. For example, with economic and business activity becoming increasingly internationalised, there is a great need for managers of both private and public tourism organisations to interact with the complex global environment. In the next decade tourism managers will require a global perspective in order to respond positively to a myriad of crises, such as overcrowding of tourist attractions, overuse and destruction of natural 
resources, resident-host conflicts, loss of cultural heritage, increased crime and prostitution, inflation and escalating land costs, and a host of other political, socio-cultural, economic and environmental problems that may be brought about or exacerbated by tourism development (Moutinho, 2000: 315).

Technological progress in the fields of transport and communications has created the conditions for increasing globalisation of the economy and of our culture. The speed of travel has improved dramatically in recent history. Towards the end of the $19^{\text {th }}$ century, it took a whole day for the mail coach to cover 160 kilometers. Today a jet airplane spans more than 1000 kilometers in a single hour. The introduction of the market economy in many countries, and their integration at the same time into the world economy, is creating an even larger world market while increasing economic growth on a global scale (as outlined in Figure 1).

\section{Figure 1 Globalisation of the tourism marketplace}

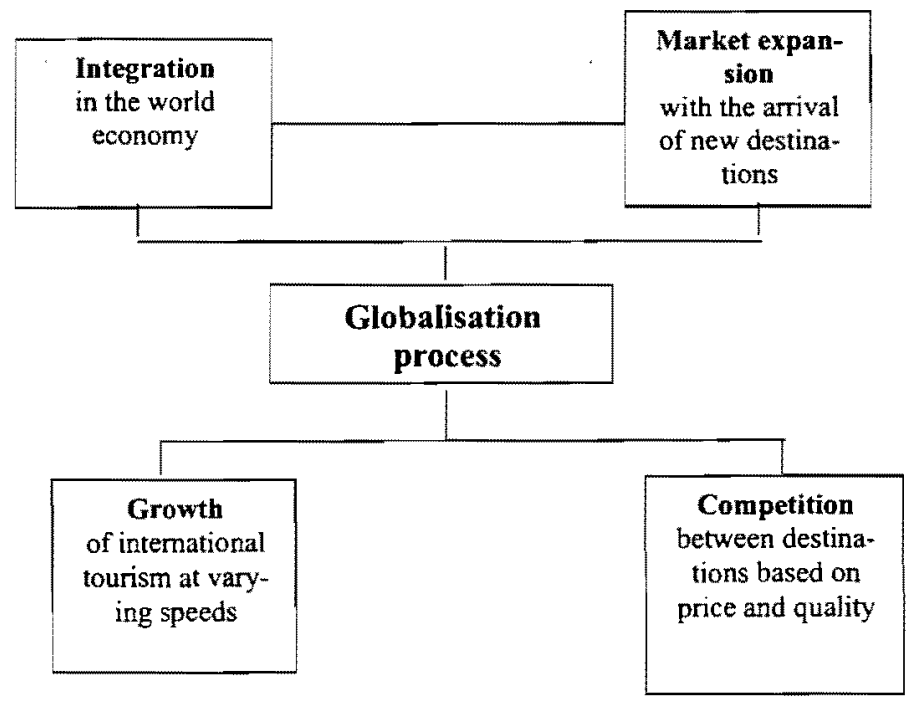

Source: Kellar (1996)

Globalisation is changing the nature of intemational tourism. Growing prosperity in the emerging nations, and the increasing international division of labour will make tourism the most important economic sector on a worldwide scale in this millennium. The market has undergone a significant expansion in recent years. New destinations have sprung up. Large tourism companies have been created, that are not dependant on any particular nation and have branches all 
over the world. They take advantage of the new technologies and offer increasingly professional, industrially standardised, uniform products (Kellar, 1996).

\section{THE KEY GLOBALISATION DRIVERS OF CHANGE IMPACTING ON TOURISM}

An important part of the tourism management process is the understanding of the key drivers of change impacting on tourism and determining appropriate responses to these changes. Broadly speaking, there are two types of influences. On the one hand, there are a number of influences that are outside the control of tourism itself and yet will have an impact upon its development (e.g. political developments, environmental disasters, etc.). These can be termed external or uncontrollable variables. On the other hand, the changing nature of the tourism industry itself is also driving change internally within the sector. These can be termed tourism-related variables.

On a practical level many of these variables and trends are interlinked and are combining to accelerate the pace of global tourism change. For example, while there is no doubt that the economic, political and social trends that will be identified in the next section, will continue to encourage the growth of tourism, the future direction and shape of the market will also change with consequent implications for the management of destinations and products. For instance, the trend towards more frequent, yet shorter trips will demand more leisure facilities close to generating markets.

The key tourism-related factors that individually and collectively have a bearing on the future shape and direction of tourism are outlined in Table land discussed below. 


\section{Table 1 Globalisation and the tourism interface}

\begin{tabular}{|c|c|c|}
\hline $\begin{array}{l}\text { Key global drivers of } \\
\text { tourism change }\end{array}$ & Impacting on the: & $\begin{array}{l}\text { Critical success factors to en- } \\
\text { sure destination competitive- } \\
\text { ness }\end{array}$ \\
\hline & Tourist (consumer) level: & \\
\hline $\begin{array}{l}\text { Emergence of the } \\
\text { "new" tourist. }\end{array}$ & $\begin{array}{l}\text { - Changing travel pat- } \\
\text { terns, antitudes, re- } \\
\text { quirements and expec- } \\
\text { tations. }\end{array}$ & $\begin{array}{l}\text { Understanding the new } \\
\text { rules of global competition }\end{array}$ \\
\hline $\begin{array}{l}\text { Technological ad- } \\
\text { vances. }\end{array}$ & $\begin{array}{l}\text { Tourism business unit } \\
\text { level: }\end{array}$ & $\begin{array}{l}\text { Anticipate and responding } \\
\text { to the strategies of leading } \\
\text { global "best practice" desti- } \\
\text { nations. }\end{array}$ \\
\hline $\begin{array}{l}\text { Global economic driv- } \\
\text { ers. }\end{array}$ & $\begin{array}{l}\text { Increasing mergers, ac- } \\
\text { quisitions, strategic al- } \\
\text { liances and networks. }\end{array}$ & $\begin{array}{l}\text { Capitalise on the unique } \\
\text { and distinctive characteris- } \\
\text { tics of destinations and } \\
\text { brand accordingly. }\end{array}$ \\
\hline $\begin{array}{l}\text { Environmental aware- } \\
\text { ness and sustainability } \\
\text { factors. }\end{array}$ & $\begin{array}{l}\text { A strategic and market- } \\
\text { driven focus becoming } \\
\text { increasingly important. }\end{array}$ & $\begin{array}{l}\text { Make quality tourism ex- } \\
\text { periences and the profitable } \\
\text { delivery of tourist (cos- } \\
\text { tumer) value the key focal } \\
\text { point. }\end{array}$ \\
\hline - Demographic shifts. & $\begin{array}{l}\text { Destination development } \\
\text { and marketing level: }\end{array}$ & $\begin{array}{l}\text { Think globally, plan re- } \\
\text { gionally and act locally. }\end{array}$ \\
\hline $\begin{array}{l}\text { Intensification of com- } \\
\text { petition. }\end{array}$ & $\begin{array}{l}\text { Increasing emphasis on } \\
\text { responsible, sustainable } \\
\text { and participative tour- } \\
\text { ism practices. }\end{array}$ & $\begin{array}{l}\text { Manage the integrity and } \\
\text { authenticity of destinations } \\
\text { in a sustainable manner. }\end{array}$ \\
\hline $\begin{array}{l}\text { An increasingly impor- } \\
\text { tant relationship be- } \\
\text { tween tourism and } \\
\text { peace. }\end{array}$ & $\begin{array}{l}\text { Destination marketing } \\
\text { increasingly innovative, } \\
\text { strategic, participative } \\
\text { and focused on tech- } \\
\text { nology-based market- } \\
\text { ing tools. }\end{array}$ & $\begin{array}{l}\text { Acknowledge "people } \\
\text { power" as the key to suc- } \\
\text { cessful and sustainable } \\
\text { tourism. }\end{array}$ \\
\hline $\begin{array}{l}\text { Regional trade blocks } \\
\text { and the rise of the city- } \\
\text { state. }\end{array}$ & & $\begin{array}{l}\text { Develop the vision, leader- } \\
\text { ship, culture and mecha" } \\
\text { nisms to continuously adapt } \\
\text { to global "waves" of } \\
\text { change. }\end{array}$ \\
\hline $\begin{array}{l}\text { Increasing importance } \\
\text { of safety, health and } \\
\text { ethical issues. }\end{array}$ & & \\
\hline $\begin{array}{l}\text { Increasing focus on } \\
\text { human resource devel- } \\
\text { opment and knowledge } \\
\text { transfer. }\end{array}$ & & \\
\hline
\end{tabular}




\subsection{The emergence of the "new tourist"}

The conventional ways of addressing tourist motivation and behaviour are rapidly becoming outdated. For example, it is no longer possible to predict the purchasing habits of tourists simply by labeling a group as "upmarket" or "price conscious". In the current tourist market various paradoxes in tourism behaviour are emerging where existing opposites occur simultaneously. Greater risk taking and greater security and greater sameness and greater diversity increasingly occur side by side. For example, it is not strange to find chartered accountants getting back to nature with bungee jumping and river rafting, but then also campers who drive luxury, air conditioned $4 \times 4$ vehicles to "rough it" in the nature areas of Botswana. The same individuals may shop at both a budget-oriented discount store and a famous department store and buy take-aways from Kentucky for lunch and dine at an exclusive upmarket restaurant for dinner. The reality is that tourism, leisure and recreation lifestyles are increasingly contradictory and inconsistent.

Of particular relevance to the tourism industry in Southern Africa is that tourists from knowledge-based economies (e.g. Western Europe and the USA, which comprises approximately 70 per cent of South Africa's overseas visitor arrivals) are increasingly found to be more experienced, more discerning, and more demanding. In particular, they are seeking more individualised experiences, often characterised as special-interest travel. Such travelers "are more interested in enriching their lives with experience rather than hands-off entertainment. They seek interactive, highly involved, quality travel experiences, focusing on indepth coverage of the special interest topic or destination at hand" (McIntosh et al., 2000: 689).

In terms of the future demand for international tourism, it is increasingly fashionable to talk of the rise of the "new tourist", a term coined by Poon (1993). A "new tourist" is described as an individual who will shun the homogenised, mass market tourism products and destinations in favour of a more adventurous, active and individualised approach to holiday taking. The "new tourist", which is increasingly drawn from an older age group, is knowledgeable, well travelled, educated, discerning, demanding, environmentally aware and prepared to pay a premium for high quality products and services.

This shift has major implications for tourism providers in Southern Africa, as the motivations for travel move away from passive sun, sand and sea experiences towards educational and curiosity motives. At the same time it is argued that travel will increasingly be shaped by flexible working practices and early retirement. This increasingly knowledgeable and sophisticated new tourist can now be catered for by a tourism industry that is firmly embracing the marketing 
concept, and which is further facilitated by technological developments such as the internet, global distribution systems and database marketing.

A key question that emerges in Southern Africa is at what rate the traditional annual family holiday mostly spent at a beach resort, may be gradually superseded by multi-interest travel and a range of creative and innovative travel experiences (such as activity, adventure, leaming and nature-based experiences). Cooper et al. (1999: 454) argue that, particularly with regard to international tourists, these trends will see the relative importance of conventional tours decline in favour of independently organised tourism.

A practical trend that could increasingly impact on the tourist travel patterns from Southern Africa's key source markets was highlighted in the WTO Report (1999) on leisure time. It was found that pressures on job security are growing in the industrialised world to the extent that employees are increasingly voluntarily working longer hours and foregoing some of their paid leave entitlement. This leads to growing difficulty in scheduling leave periods, particularly for dualincome households. One of the implications of this growth of "time poor-money rich" people will be to pursue leisure activities which maximise their available time (e.g. short break holidays, theme parks, cruise holidays). For others, the release from their job pressures will be manifested through a desire for complete relaxation without the need to make any decision or engage in exacting activity - a scenario that augurs well for the further growth of all-inclusive resort holidays.

The preceding perspectives clearly indicate that the emergence of the "new tourist" has various implications for the tourism industry. So, for example, the emergence of the knowledge-based society is significant for tourism as travel products are merged with education and entertainment. This creates opportunities for info-tainment or edu-tainment at destinations and specifically at commercial attractions through interprepretation and education programmes. The increased sophistication of the "new tourist" will also impact upon product development throughout the industry. It can safely be assumed that not only will there be increased requirement standards of product design, efficiency and safety, but the tourist will also be more critical of products and services and have the experience to compare offerings. Furthermore, as the "new tourist" becomes increasingly conscious of value for money rather than simply price, other elements of the marketing mix will become more important. This could mean that quality will remain a key attribute in tourism product development and the "new tourist" will increasingly expect customer convenience in its various forms.

In Southem Africa it can be argued that as international tourism expands, the number of "new tourists" will undoubtedly grow, but for the foreseeable future, 
their numbers will still be overshadowed by the bulk of tourists who will continue to bury packaged holiday products, visit popular destinations and make their holiday choices primarily on the basis of price.

\subsection{The acceleration of technological advances}

One certainty about the future of technological advances is that the rate of change will continue to increase. Technology has already revolutionised the organisation, management and day-to-day nunning of businesses in the tourism industry. IT has helped to reduce some of the costs of business operations. The introduction of CRSs and GDSs has assisted in the globalisation of tourism business activity and the impact of the Internet is all embracing. Many destinations, tourism suppliers and airlines have World Wide Websites and many now offer incentives to book on-line, with discounts to offset the commission normally paid to travel agents. The use of technology will certainly continue as tourism suppliers increasingly target the on-line booker, providing the flexibility of booking in your home.

\subsubsection{Technology will enable the jet aircraft of the future to travel further,} faster and carry more people

Continuing developments in transportation will reduce travel times and make the remoter regions of the world more accessible to tourists. Key changes and developments that are underway, include:

- Airbus Industrie of Europe is currently working on a model, the $\mathrm{A} 3 \mathrm{XX}$, which is projected to have 15 per cent to 20 per cent less operating costs than the Boeing 747 . It will seat 550 economy, business and first class passengers.

- Airospatial of France is researching a Concorde successor, which will be able to fly 300 passengers across $10000 \mathrm{~km}$ at supersonic speeds.

- NASA estimates that in the first years of the $21^{\text {st }}$ century there will be orders for more than 500 SST planes (moving at twice the speed of sound) worth a total of US\$200. On the SST, a flight from Tokyo to Los Angeles would be cut from 11 hours to 5 hours (Hannifin \& Le Quesne, 1998).

A major implication of the development of the new range of jet aircraft as outlined above, will be the further reinforcement of the "hub and spoke" transport network arrangement with main airports as the hubs of regional transport systems. There is intense competition between countries and airports to encourage the large passenger airports to use their airport as a hub before passengers are redistributed to other destinations. For example, East Asia has seen a spate of airport development and redevelopment in recent years, such as Bangkok, Hong Kong, Kuala Lumpur and Singapore, in order to compete for hub status (Hall \& 
Page, 1999). In South Africa, Johannesburg International Airport is being upgraded and positioned as the hub airport for Southern Africa with a wide array of spokes into the rest of the sub-continent.

\subsubsection{The explosion in communication technology}

Arguably the most significant impact that technology will have on the tourism industry is in terms of advances in communication technology. One of its most direct impacts has been the role of the Internet. Internet usage is currently doubling in volume every 100 days and the value of commerce transacted on the Internet is now expected to multiply by a factor of 50 to US $\$ 6$ billion by 2002 (King, 1998). The Internet will not only increasingly impact on promotional channels, but will also be instrumental in cutting out some tour wholesalers and retailers from the travel product supply chain, thereby enabling direct communication between the supplier of the tourism product and the consumer. The overall impact on travel agencies and other suppliers is as yet unqualified but it is sure to be substantial (Sheldon, 1997).

Furthermore, information technology has the ability to dramatically impact on destination images and by implication, visitor flows. Technology will without a doubt increasingly influence the way that tourism products are promoted and sold; for example, the viewing of virtual reality simulations of resort facilities prior to making a booking and sales via networked computer systems such as the Internet (Youell, 1998).

From a transactional perspective it is projected that in the next decade tourists will increasingly use smart cards at destinations for travellers cheques and for discounts. Before travelling, the Internet will increasingly make it possible for visitors to view different rooms and facilities at a hotel in real time through strategically placed cameras. CD-Rom brochures will eventually replace paper brochures. On-line booking via the Internet and e-ticketing will become established and grow strongly in the next few years. Databases on traveller information about preferences and lifestyle will also increasingly be sold on a commercial basis (Vellas \& Becherel, 1999).

3.2.3 The impact of technology advances on the built tourism environment of the future

According to futurologists William Zuk and Douglas Olesen, hotel and resort design will be revolutionised with smart building materials, super-structural systems and environmental and energy advances (op. cit., 1998). 
We may see super-structures with high-rise buildings up to 500 stories high. Whole areas could be covered using geodesic domes to protect against the elements and extreme climates and resorts may be built on platforms above the water. Solar panels used for both cooling and heating, smart walls that keep rooms at constant temperatures and portable inexpensive fuel sources will help save energy (Wolff, 1998).

Possible future developments in terms of the built environment are:

- Massive multi-storey, floating hotels moored offshore and containing restaurants, shopping arcades, gymnasiums and glass-enclosed elevators that carry tourists directly to the sea floor.

- Underwater hotels that attract the more adventurous leisure travelers who can peer at the undersea life through their bedroom windows.

- The theme parks of the future will be individual-experience centres where technology will let people role play almost anything. For example, in California a Victorian-style high-tech house has been constructed that transports visitors back into a romantic version of the previous century. The house includes a three-dimensional film theatre that employs vibrating chairs to simulate motion, a scent-projection device that is coordinated with images on the screen and a state-of-the-art sound system (Moutinho, 2000).

\subsubsection{Can virtual reality become the substitute for the actual tourism experi-} ence?

A key point of debate is whether technological innovations such as Virtual Reality (VR) could possibly replace the authentic travel experience. By simply strapping on a body suit and plugging into a VR programme one can be transported to the sights, sounds and sensations of, say, the Okavango Delta, the Serengeti and the Kruger National Park, virtually within minutes. The tourist can safely experience the destination without being at the risk of the side effects of travel. However, the destination also forfeits the positive effects of income and jobs creation and regional development.

While one view is that the possibility of "experiencing" a destination without actually visiting it is merely a fantasy, it does seem logical that such an approach could find acceptance among members of a knowledge-based society. If successful, there can be no doubt that "Virtual Reality tourism" could have significant implications to the tourism industry. While the debate continues regarding the potential impact of VR on tourism, it is unlikely to completely remove the pursuit of "getting away" to relax in a different environment and place.

In terms of technology, one of the most significant changes occurring globally is 
the continued growth of artificial environments for tourism and leisure activity. This is reflected in the global theme park industry, which generates US\$11 bn a year, with an estimated 119 theme parks spread across the world. These parks received in excess of 300 million visitors in 1996, many attracting over one million visitors each a year (Page et al., 2001). Proponents say that, as cocooning behaviour increasingly positions the home as a central and secure base for leisure activities, VR may suppress demand for the real thing. Opponents contend that VR will simply wet the appetite for more travel through enhanced exposure to, and awareness of, the product (Cooper et al., 1999).

The technological advances outlined above may make life simpler and more convenient for tourism service providers and tourists. However, many (possibly the majority of) travellers, still seem to value the personal touch of dealing with another human being. Most people, especially older travellers, do not view doing-it-themselves as saving time, but as an unnecessary added effort (Cook $e t$ al., 1999).

\subsubsection{Will global technology trends revolutionise the tourism industry in South Africa?}

The WTO (1999: 36) postulated the following technological developments that could revolutionise the tourism industry in the next decade and beyond:

- the increasing use of smart card destination loyalty schemes where the user gets discounts for using the card at a destination and, in return, the destination gains valuable marketing information about its customers;

- plastification of travellers' cheques, again using smart card technology;

- Internet video telephony whereby consumers can "test drive" a prospective holiday by viewing current pictures through cameras placed in hotels, clubs, restaurants, and other sites in the destination and transmitted via the Internet;

- intelligent agent computer programmes which are a combination of preentered information (e.g. likes and dislikes in respect of holidays) and observed behaviours in use of on-line booking patterns to make suggestions on possible options for the user, thus saving time in "surfing" the Internet;

- CD roms are likely to be increasingly used as electronic brochures, saving time in the inspection of paper brochures. These are likely to be sponsored by both tour operators and destinations;

- on-line booking via the Internet is certain to grow rapidly over the next decade with access available to most of the population of industrialised countries. Though transfer of such access to usership in respect of travel bookings may take time, it is clear that this medium will achieve increasing uptake in the next 10 to 15 years; 
- e-ticketing (or ticketless travel) is being operated on a limited basis already, by a number of airlines;

- central databases of traveller information will provide extensive insight into individual travellers' preferences and behavioural patterns, and will be available commercially.

\subsection{Globalisation and the economic drivers of tourism growth}

Two of the most important driving forces behind changing travel pattems in this millennium are globalisation and economic growth. Although economic growth rates in much of the developed world are expected to stay relatively low in the short and mid-terms, several developing countries are expected to maintain relatively high levels of growth (Hall, 2000). Eventually, as many as nine of the top 15 world economies will be from today's Third World nations. For example it is projected that within a generation, China will overtake the USA as the world's largest economy. According to World Bank figures, the top ten economies are likely to be China, USA, Japan, India, Indonesia, Germany, South Korea, Thailand, France and Taiwan (Youell, 1998).

The long-term implications of growth in these tourist-generating regions for world tourism cannot be overestimated. With their large populations the emergence of a new middle class with increased leisure time and greater discretionary income will have repercussions throughout the tourism system, which may be likened to the significance of growth in Japanese outbound travel in the late twentieth century (Hall, 2000).

\subsection{The globalisation and convergence of tourism, leisure, sport and en- tertainment}

One of the most significant global trends in tourism is the convergence of the tourism, leisure, sport and entertainment industries. Developments in communication technology have provided coverage for global sports, events and entertainment, enhancing the capacity of events to increase their televised audience. In such a scenario the desire of growth coalitions to bid for and host events may be expected to increase (Hall, 2000).

\subsection{The growth in international alliances}

Another dimension of economic globalisation with implications for tourism is the growth of international alliances between various airlines and other parts of the tourism industry, including the accommodation and hospitality sectors. Although airline deregulation and freer trade arrangements may provide for new entrants in the aviation industry, the economies of scale of the existing alliances 
will make it extremely difficult for new entrants to compete. The supply of these transnational corporations could have major consequences for some destinations, as their capital is shifted according to the ability to take advantage of differences in labour costs, exchange rates and tax benefits from government. Simultaneously, the ability of secondary tourism businesses to adapt and survive in the international political economy of tourism in the 21 st century will very likely depend on the creation of appropriate network arrangements between businesses (Buhalis \& Cooper, 1998).

\subsection{Trends towards "sameness" and "distinctiveness"}

One of the key outcomes of increased globalisation is the trend towards "sameness" around the world, but with indications that there are increasingly strong counter pressures to maintain individuality and cultural distinctiveness. A visit to any major city in the world demonstrates how information, economic pressures and the tendency to imitate, has left the world "less different" than it was decades ago. McIntosh et al. (2000) however argue that the human entity, while recognising the pragmatic value of sameness, is determined at the same time to make every effort to preserve and enhance his or her unique identity. Creating unique and distinctive tourism experiences that are true to the theme and character of a particular destination, may be one of the key challenges facing tourism developers and destination marketers in this millennium.

\subsection{The increased concentration of economic power}

A major trend that could have significant implications in the long run, is that the concentration of capital is increasingly in the hands of a few major players in the tourism sector; a trend that also drives tourism towards the performance indicators and business practices demanded by the finance industry. The pace of concentration being generated by both horizontal and vertical integration is such that for medium-sized companies in tourism the days ahead may be difficult. A particular problem associated with this trend is that most of the larger corporations do not have a committed longer-term relationship with a specific destination. Some commentators feel that they will therefore be less sensitive to the impact of their operations on the host environments, economies and communities. In addition, small and medium-sized tourism enterprises and local destinations fear the relationships that can emerge from dealing with large companies. To complement these global players a new breed of successful, smaller, niched, operators are emerging as influential in the future of tourism (Cook et al., 1999). 


\subsection{Geographic boundaries are becoming obsolete from a tourist perspec- tive}

Key challenges brought about by globalisation are, among others, that tourism service offerings must have universal appeal, and product development must stress adaptability to succeed in a global marketplace. From a consumer perspective, boundaries and territories are becoming obsolete, replaced by the universal appeal for the latest, newest and best value in both products and services. Moutinho (2000) warns that winners will recognise globalisation as the macro force for success, while losers will be those who fail to understand or adapt to it.

\subsection{The importance of developing countries in the future tourism sce- nario}

In spite of the globalisation of tourism, many developing countries are still in several ways removed from the mainstream of international tourism except for the newly industrialised countries, which are also new tourism markets.

A critical evaluation of the situation at the turn of the century indicates that both in terms of visitors and revenue tourism has been concentrated in three main regions, namely Europe, North America (USA and Canada) and the Far East and Pacific countries. In 1997 these three regions accounted for 84.3 per cent of international visitors and 87.3 per cent of revenue. It follows that international tourism accounts for only 15.7 per cent of visitors and 12.7 per cent of income in all African countries, Latin America, the Caribbean, the Middle East and South Asia (Vellas \& Becherel, 1999).

On a positive note, there are various factors that could contribute to the growth of tourism in developing countries during the first decades of the new millennium,

These include:

- Opportunities offered by electronic distribution channels: Developing countries and new markets can be represented on an equal footing in the global market, using electronic distribution channels such as the Internet. It is becoming increasingly affordable and cost-effective to set up a website that can be accessed by any computer linked to the global network.

- The need for tour operators to offer new destinations (geographical diversification): Developing countries can respond to the needs of the main generating markets by offering alternative destinations.

- The need for tour operators to offer new products (product diversification): Tourism demand is increasingly orientated towards new types of experiences, 
particularly cultural and environmental. New markets in developing countries often have a rich natural, cultural and historical heritage, which tour operators are promoting to cater to changing demand (op. cit., 1999).

\subsection{Increasing environmental awareness and sustainability factors}

From the literature it is apparent that the environment is increasingly taking "center stage" in tourism. As the Tourism Policy Fonum pointed out: "Development must, in the future, be compatible with the environment". The Fonum also emphasised "..that tourism is among the better alternatives for land use". While such compatibility is positive and encouraging, there are other areas where compatibility between tourism and the environment is more complex. For example, the use of fossil fuels for transportation and their polluting effect can have major implications in the future (McIntosh et al., 2000). As a consequence, the sustainability of tourism in the long term could be seriously jeopardised unless alternative nonpolluting energy sources become available and are utilised.

On a practical level, there is a wide range of environmental variables that will significantly impact on the future of tourism. These include long-term factors such as global warming and the erosion of the ozone layer. On the demand-side, fear of skin cancer and eye cataracts may reduce the demand for products such as beach tourism that, in tum, will impact upon destinations and product development. On the supply-side, the raising of the earth's temperature and the consequent impact on winter sport destinations, as well as rises in sea levels, will increasingly affect tourism. As much of tourism investment is found in locations fringing the coastline, and as vital tourism resources such as the flora and fauna of destinations could permanently be altered by global warming, tourism stakeholders are faced with major challenges in the future (Cooper et al., 1999).

Of major concern for the future of tourism is the extent to which population growth and demands for increased material standards of living, will put pressure on the planet's scarce natural resources. Despite the assurances of some futurists such as Naisbitt (1994) that technological solutions will be found, there are still natural limits to growth that the goals and values of sustainable development are seeking to address. In tourism terms it raises questions about the increased cost of fuel from about the year 2020 onwards (Hall, 2000).

\subsubsection{Visitor management - a key to sustainability}

The growing demand by tourists to visit some of the world's "honey pots" is causing many destinations to consider methods to manage visitors more effectively, for their own enjoyment and also for the protection of the product itself. So, for example, the popularity of certain national parks in the United Kingdom 
and the United States has led to the consideration of a ban on motor vehicles entering some of the parks. During peak months, Florence insists that coaches prebook if they want to visit the centre of the town. Time-controlled ticketing for attractions has also been implemented at many key European attractions, and certain ones have been declared off-limits to tourists, such as Stonehenge in the UK (WTO, 1999).

Hall (2000: 93) wams that growth in tourist numbers as well as overall pressures stemming from population growth, particularly in developing countries, will mean that access to tourism facilities will need to be restricted if their environmental value is to be maintained; often by the adoption of a user-pays philosophy in order to maximise returns to government or private agencies.

\subsubsection{The increasing focus on green issues}

Green issues are expected to dominate the future strategies of tourism businesses and destinations. Vellas and Becherel (1999) argue that tourism businesses will increasingly incorporate environmental policies into their strategies in order to attract more business either by making the environment the focus of their product or to target specific consumers, and/or by using their environmentalawareness credentials to enhance their image.

On a practical level, one technology that is being embraced by the tourism industry is recycling. For example, the National Restaurant Association in America has reported that more than 7 out of 10 operators purchased products made from recycled materials and roughly 3 out of 4 operate recycling programs (Cook et al., 1999).

More green hotels are appearing internationally, but also in Southem Africa. In a green hotel, for example, guests place a card on their pillow that indicates whether or not they would like their sheets changed and only the towels left on the floor are replaced. These simple practices save millions of litres of water and prevent the release of tons of detergents into the environment. From an operations standpoint, it saves on the cost of linen, labour and equipment. Most employees and guests are embracing green hotel practices with enthusiasm. Recycling holds the future promise of additional operating efficiencies and environmental benefits (Cook et al., 1999).

Destinations will also increasingly develop and promote sustainable tourism and eco-tourism to enhance their appeal to a wider tourism audience. A note of caution is however sounded by Vellas and Becherel $(1999: 310)$ that in practice these strategies may not in all instances represent genuine consideration by the organisations towards green and sustainable issues. There is concem that envi- 
ronmental issues are increasingly used and sometimes exploited as a marketing ploy to tout for more business.

\subsubsection{Agenda 21 and sustainable tourism in the future}

Agenda 21 is a comprehensive programme of action adopted by 182 governments in 1992 at the United Nations Conference on Environment and Development (UNCED), better known as the "Earth Summit". It provides a blueprint for securing the sustainable future of the planet, from now on into the $21^{\text {st }}$ Century. In short, Agenda 21 represents a commitment to an important strategic thrust, which now requires specific initiatives from all levels of society and from business communities (Youell, 1998).

The WTTC (1995) has translated Agenda 21 into a programme of action for the tourism industry, highlighting priority points for both the public sector and commercial operators. For govermment departments, national tourism organisations, companies and representative trade organisations, the WTTC sees the overriding aim in relation to Agenda 21 as establishing systems and procedures to incorporate sustainable development considerations at the core of the decision-making process and to identify actions necessary to bring sustainable development into being.

Building on the philosophy and foundations provided by Agenda 21, the tourism industry itself is increasingly demonstrating that it is indeed responsible and acting to curb some of the excesses of past development. So, for example:

- The WTTC, (referred to above), has introduced an environmental awareness programme, Green Globe.

- The Pacific Area Tourism Association (PATA) has launched an environmental membership and endorsement entitled Green Leaf.

- "Green Suitcase" sets out environmental quality standards for resorts, accommodation and travel agents in Europe, developed by Ökologischer Tourismus in Europe.

- Companies have initiated awards, such as Tourism for Tomorrow by British Airways (Cooper et al., 1999).

\subsection{Demographic shifts shaping the future direction of tourism}

Possibly the key demographic factor that will affect the future of tourism is the ageing of the world's population. This substantial demographic change has occurred because of dramatic improvements in health care and is predicted to continue well into the coming centuries, as long as the worid's resources are able to support the increases in population. Currently, 11 per cent of the population is 
aged 60 and above. By 2050, one out of five will be 60 years or older; and by 2150 , one out of three persons will be 60 years or older. However, the older population itself is ageing. The increase in the number of very old people (aged 80 and older) between 1950 and 2050 is projected to grow by a factor of from 8 to 10 times on a global scale. As well as general ageing of the world's population, there are also substantial regional differences in the aged population. For example, currently one out of five Europeans is 60 years or older, but one out of twenty Africans is 60 years or older (Hall, 2000).

In some developed countries today, the proportion of older persons is approximately one in five. The United Nations predicts that during the first half of the next century this proportion will reach one in four and, in some countries, one in two (United Nations, Division for Social Policy and Development, 1998). Based on the fact that the majority of the world's tourists come from the developed countries (WTO, 1996), such a demographic shift will have major implications for the international tourism industry. Not only will certain types of tourism such as cruising and soft adventure tourism, continue to grow in popularity, but also the provision of health and related facilities for retirees may become increasingly important in destination development strategies.

Other demographic factors could also be significant. For example, the breakdown of the traditional nuclear family in many western countries marked by increased single parenting, people marrying later, more people never marrying, and many people never having children, will not only influences demographic characteristics but will also affect the pattern of holiday taking and leisure travel (Hall, 2000).

\subsection{Moving into an era of alliances and hyper competition}

Alliances and partnerships in tourism development and promotion is growing at various levels in the tourism industry. In countries that are still developing their tourism industry or where the private sector is weak, the public sector will remain at the forefront of destination marketing as it is today. However, where tourism is well established it is increasingly apparent that the role of the public sector is more of a supporting, facilitating and enabling nature.

In the private sector, airlines have pioneered the development of cooperative alliances to gain greater brand recognition and operating synergies. For example, the alliance between British Airways and American Airlines that signaled possible dominance in the north Atlantic marketplace, gave rise to the competing Star Alliance. The Star Alliance created a global airline network consisting of United, Lufthansa, Air Canada, SAS, Thai Airways, and Varig, which together serve almost 600 cities in over 100 countries. 
A trend that seems likely to continue in the foreseeable future is the development of partnerships between the government and the private sector. Such cooperative relationships already exist: from the World Tourism Organisation (WTO) through to national, provincial and local governments (WTO, 1998). Given the fact that direct government funding for tourism is increasingly under stress, the creation of such relationships is hardly surprising.

An increasing global trend that is also manifesting itself in Southem Africa, is the increase in subcontracting of many functions needed to support guest services. Operations such as cleaning, laundry, and food service will increasingly be performed by outside contractors. In some situations the operating company will own the facilities and equipment and rely on the expertise of outside contractors to provide and manage labour. In other situations space will be leased to subcontractors, who in turn will make the investments in equipment as well as manage the entire operation. This trend is already becoming evident in the number of fast-food outlets that are appearing in hotels, airports, theme parks, service stations and food courts in malls.

On another level, hyper competition in the tourism industry is intensifying at many levels and is being perpetuated by four broad processes. These are:

- Customers require improved quality at lower prices

- Rapid technological change, enhanced through the use of IT

- The expansion of very aggressive companies which are willing to enter markets for a number of years with a loss leader product; with a view to destroying the competition so that they will hamess the market in the long term

- Government barriers towards competition are progressively removed throughout the world, with some markets still holding back on the deregulation in the aviation sector (D'Aveni, 1998).

The implications of hyper competition and technological change for the tourism sector are that the role of the consumer will become increasingly important, especially in relation to service quality. Service quality will therefore continue to be a major component of the future shape of tourism provision.

\subsection{The increasing emphasis on the relationship between tourism and peace}

The vital relationship between tourism and peace is receiving increasing attention, particularly since the first groundbreaking global tourism conference on the very important theme "Tourism: A Vital Force for Peace" held in Vancouver, Canada during October 1988. This conference, which has been a major building block in progressing the relationship between peace and tourism, was attended 
by more than 600 delegates from 64 countries around the world. The main focus of the conference was to explore ways in which the world's hundreds of millions of international travellers could, by increasing interests, improving attitudes, and engaging in various social and other activities, contribute to better mutual understanding and appreciation - an important contribution towards world peace (McIntosh et al., 1995).

One of the key outcomes of the conference, which could have particular relevance to the future of tourism, particularly in Southern Africa, was the Credo of the Peaceful Traveller.

\section{The Credo of the Peaceful Traveller}

Grateful for the opportunity to travel and to experience the world, and because peace begins with the individual, I affirm my personal responsibility and commitment to:

- Journey with an open mind and gentle heart,

- Accept with grace and gratitude the diversity I encounter,

- Revere and protect the natural environment that sustains life,

- Appreciate all cultures I discover,

- Respect and thank my hosts for their welcome,

- Offer my hand in friendship to everyone I meet,

- Support travel services that share these views and act upon them, and

- By spirit, words and action, encourage others to travel the world in peace.

Source: McIntosh et al., (1995)

The vital and often fragile link between tourism and peace in Southem Africa is without doubt critical for the future. In this regard it is important to recognise how much progress has taken place since the dark years of sanctions and isolation, which is reinforced by the announcement that Mpumalanga will host the continent's first African Peace Through Tourism Conference in March 2002 (Travel Now, May 18, 2001).

\subsection{Regional trade blocks and the rise of the City-State}

A trend that is becoming increasingly apparent is the growing importance of regional trade blocks. One of the best current examples in this regard is the new "borderless Europe", which is fast becoming a reality. The North American Free Trade Agreement has created another block. In response to these two initiatives, the Asian nations are starting to reflect on the need for an equivalent arrangement (McIntosh et al., 2000). 
One of the major goals of regional integration (e.g. in Europe) is to arrive at common standards, a common currency, and a more common political system. A key implication from a tourism perspective is the effective elimination of borders, which could greatly facilitate travel flows. At the same time, it is postulated that over time, it will greatly reduce national distinctiveness and thus the appeal of a particular country as a unique travel destination. There is increasing evidence that as a reaction to the decline of national identities, there will be a reactive rise in the importance of major metropolitan centers or city-states. McIntosh et al., (2000) argue that these city-states may become the focal point for both economic development and for individual identity. Of particular relevance to tourism is the possibility that the new city-states may also become the primary basis for destination development and promotion whether it is as cultural centres (such as Dublin), gateway centers (such as Johannesburg) or for hosting major events (such the 2008 Olympics in Beijing).

\subsection{The increasing importance of health, safety and ethical issues in tour- ist decision-making}

The terms "tourist health" and "tourist safety" relate to concerns for the wellbeing, welfare and wider safety of the visitor not only while travelling from the origin area to the destination area, but particularly the way in which their health and personal safety are affected by their activities in the destination.

In the area of physical (as opposed to economic) security, it is increasingly apparent that risk of physical danger diminishes the prospects of a given tourism destination or travel-related firm. War and turmoil in parts of Africa, Eastern Europe and the Middle East have affected tourism both locally and worldwide. Terrorism aimed at US air carriers has diverted traffic to competitors (McIntosh et al., 2000). The horrific terrorist attacks on the World Trade Centre in New York and the Pentagon in Washington during September 2001, has possibly changed the shape and direction of tourism for decades to come.

Concern for health is of increasing importance, particularly for older travelers. In a different but related vein, the growing threat of AIDS has added yet another dimension of concern - only this time for younger segments of the population. Tourists' behaviour too, is a threat to tourism as the spreading of AIDS may render some otherwise attractive destinations no-go areas while increasingly intense campaigns against sex tourism may also alter tourism flows and motivations. In some parts of world disease and decreasing levels of safety will constrain the expansion of tourism (Cooper et al., 1999).

At the macro-level, the above factors are largely beyond the control of tourism and their consequences may be severe, yet at the micro-level, the tourism indus- 
try will increasingly work towards managing issues such as safety and security at the destination.

According to Clift and Page (1996) there is increasing evidence that adverse experiences (e.g. accidents, injuries and health problems associated with visiting unfamiliar environments) may pose major problems for the tourism industry, particularly given its image as a business selling positive holiday experiences to improve one's quality of life. In extreme cases public perception of the destination may affect the volume of tourist visits, where tourists report a high incidence of health problems during their visit.

Page et al. (2001) argue that although a number of studies have examined the media impact and effect of crime and security issues for tourists and the tourism industry (e.g. Pizam \& Mansfeld, 1996), current thinking and research efforts have not grasped the concept of tourist well-being, preferring to focus on individual dimensions for safety that impact on tourists' experiences (e.g. crime, health and food safety). Tourist accidents can also have a major impact on tourism, e.g. in adventure tourism, which is one of the fastest growing sectors of the Southern Africa tourism industry. Of particular significance is the fact that various Southem Africa adventure activities such as white water rafting and mountain recreation, appear to present an unacceptably high risk of serious and fatal injury to the clients.

Aside from injuries, there is growing evidence that tourists as consumers are becoming willing to take legal action when their tourism experience falls below the minimum acceptable levels. There are even legal firms specialising in taking action against tour operators on behalf of their clients where their holiday experience was totally unacceptable, due to service breakdowns. For the tourism industry, health and safety issues are an area that will become more important as the consumer becomes more litigious (Page et al., 2001).

In its 2020 Vision, the WTO (1999: 30) summarises the following key issues pertaining to tourism safety in the future:

- The safety of air traffic control systems is certain to play a major part in overall air travel safety in the coming years. With the large growth in air travel, many air traffic control systems, even in the US, are struggling to cope.

- Tourism will not flourish in destinations in civil turmoil, at war, or where tourists' health or security is perceived to be under threat. Tourist kidnappings appear to be on the increase with incidents worldwide doubling in the last five years. Terrorist groups are becoming more aware that killing or holding tourists for ransom makes good news.

- The importance of health within countries and resorts has recently been high- 
lighted by the withdrawal of many tour operators from the destinations, where many hotels were declared "unclean" after several tourists were taken ill. Outbreaks of disease have a temporary impact on tourists travelling to worldwide destinations, but the longer-term damage to tourism would be caused if a disease were actually transmitted from its origin around the world through air travel.

\subsubsection{The increasing targeting of tourists by terrorist groups}

A very unfortunate and more insidious trend in the political dimensions of tourism will possibly be the increased targeting of tourists by terrorist groups for political ends and hostage taking of tourism for ransom and/or publicity. The ability to raise almost instant international media profile through attacks on tourists provides many opportunities for terrorist groups to attempt to achieve their political ends.

Furthermore, the continuing growth in major international events and the numbers of travellers to peripheral tourism regions for reasons of adventure, nature and/or culturally orientated motivations can only serve to create further potential for attacks on tourists, particularly when the division between rich and poor in terms of wealth and access to resources continues to grow in the developing world (Hall, 2000).

\subsection{Ethical behaviour - a key tourism priority in the future}

An issue which is receiving increasing attention is the growing concern with ethical business practices in tourism which is reflected in the WTO (1999) development of a Global Code of Ethics for Tourism in recognition of the need to enshrine many of the principles of global action on the environment, the rights of tourists and workers considering global legislation from other bodies and out comes such as Agenda 21. The full text of the Code can be viewed at:

http//www.world-tourism.org/pressrel/CODEOFE.htm.

\section{Table 2 A Global Code of Ethics for Tourism - The Basic Principles}

- Tourism's contribution to mutual understanding and respect between people and societies

- Tourism is a vehicle for individual and collective fulfillment

- Tourism as a factor of sustainable development

- Tourism as a user of the cultural heritage of mankind and contributor to its enhancement 
Table 2 continued

\begin{tabular}{|c|c|}
\hline \multicolumn{2}{|r|}{ - Tourism as a beneficial activity for host countries and communities } \\
\hline & Obligations of stakeholders in tourism development \\
\hline & Rights to tourism \\
\hline & Liberty of tourism movements \\
\hline & Rights of workers and entrepreneurs in the tourism industry \\
\hline & $\begin{array}{l}\text { Implementation of the principles of the Global Co de of Ethics for Tour- } \\
\text { ism }\end{array}$ \\
\hline
\end{tabular}

Source: WTO (1999)

This Code of Ethics is a wider recognition of the understanding and complexity of tourism as an activity that has wide ranging implications for the tourist, the tourism employee, countries and the natural environment. Linked to these concerns are the legal and moral concerns with the spread of sex tourism and the impact on children, as reflected in establishment of the Child Prostitution and Tourism Watch by the WTO and other non-government agencies. A website has been established to uncover, isolate, prevent and eradicate this unacceptable face of tourism.

In the new millennium there is increasing evidence that these unacceptable elements of tourism are now gaining public condemnation and will become an increasing issue of strategic concem to stakeholders in the tourism industry.

\subsection{Increasing focus on human resources development}

The tourism industry is increasingly under pressure; changing markets, industry restructuring and more competitive domestic and intemational markets are placing great burdens on the available tourism expertise in the industry. The ability to succeed, and the future performance of tourism and related activities will depend largely upon the skills, qualities and knowledge that managers will be able to bring to their business. This will place increasing pressure on educators and trainers to play a larger role in facilitation, innovation, encouraging empowerment, motivating the workforce and, in partnership with industry, working to overcome the specific problems of tourism.

In the future, tourism education and training will have to be responsive to the changing needs of the sector. In this regard, three major trends can be identified:

- Deepening within the subject area. An evolution is taking place in tourism education and training that recognises the need for a broad-based education system. Whereas in the past the focus was predominantly on hospitality and travel agency elements, the inclusion of other key elements of the tourism chain in these programmes will ensure that the accommodation sector is well 
managed, but also that the country's attractions, transportation, events and ground handling will be professionally managed with high standards of service, destination management and guiding.

- Broadening to other subject areas. A second trend is the shifting balance between tourism course content and core management and business areas such as finance marketing, economics, accounting, etc. In the future, the tourism manager will need to be knowledgeable in say, generic marketing approaches, but will also have to be able to apply that expertise within a tourism context.

- Development of quality standards. A third trend is the involvement of international bodies such as the WTO (through their TedQual Certification system) to integrate quality standards into tourism education and training (Cooper et al., 1999).

\subsection{The key implications of the drivers of tourism change}

As is apparent from the preceding analysis of the key drivers, changes in tourism are a reality as also is the fact that tourism growth is inevitable. This means that, not only will more tourists be seeking authentic experiences in new destinations, but also that most destinations will be seeking to take advantage of these heightened levels of demand to boost income and employment. This is the case for most regions of the world, even the ones that have not traditionally been regarded as potential destinations. All of this means that it will be much more difficult for destinations and tourism businesses to be successful, particularly given the potential impacts of the key drivers of change outlined in this section. The challenge facing every destination and tourism stakeholder will therefore be to identify the key drivers of change; to determine their potential shape and direction; to evaluate the possible implications of the trend; and importantly, to develop appropriate strategic responses.

\section{CONCLUSION}

In conclusion, the various globalisation trends and developments outlined in this paper which indicate that in the future tourism will be increasingly flexible, segmented, customised and diagonally integrated rather than the mass, rigid, standardised and packaged, can be synthesised into the following key global trends that will, according to all indications, dominate the shape and direction of tourism in the $21^{\text {st }}$ century (adapted from WTO, 1999; Cooper et al., 1999; Hall, 2000):

- Increased globlalisation and localisation, forcing tourism stakeholders to "think globally, plan regionally and act locally". 
- Technology and telecommunications will permeate and dominate in virtually every sphere of the future tourism industry.

- Major emphasis in the travel process will be placed on speed, efficiency, safety and convenience. This trend will be particularly dominant in the tourism transportation sphere.

- Customers will increasingly "call the shots" through technology such as CD Rom atlases, Internet inspection of hotels and other facilities, brokers offering discounted rooms on websites, last minute e-mail low fares, etc.

- A polarisation of tourism tastes will increasingly evolve (e.g. comfort-based versus adventure-orientated).

- Globalisation in all its facets will result in a "shrinking tourism world" with increased emphasis on "off the beaten track places".

- Targeted product market development (especially theme based) will be primarily orientated to one of the three Es - entertainment, excitement and education.

- Destination image development, positioning and branding will become increasingly important in tourism marketing, More destinations focus on "image" as a prerequisite to the diversification and expansion of drawing power.

- Consumers will place increasing importance on sustainable tourism development and ethical business practices when deciding on tourism destinations and the tourism facilities they patronise.

- Intensified conflict between the increased urge to travel and the consumers' socio-environmental consciousness can be expected to manifest itself at various levels in the industry.

When interpreting these trends the view of John Naisbitt (1994), one of the foremost futurists is very relevant, namely:

Trends tell you the direction the industry is moving in. The decisions are up to you. But trends, like horses, are easier to ride in the direction they are already going. When you make a decision that is compatible with the overarching trends, the trend helps you along. You may decide to buck the trend, but it is still helpful to know it is there.

From the key trends outlined in this paper it should be apparent that managing change in a fast moving business sector such as tourism will continue to pose enormous challenges for tourism businesses and destination managers and marketers in the $21^{\text {st }}$ century. What will be increasingly critical in the future will be tourism managers' ability to be adaptable and flexible to change, particularly in fast moving areas such as tourism. Increasingly, tourism managers will have to undertake not only the role of management, but also the dynamic role of "agents of change". Tourism Managers will increasingly have to understand how systems and organisations work and function to create desired outcomes. 
The key global trends outlined in this paper particularly highlighted the fact that the strategic management process in tourism boils down to planning based on uncertainty. The challenge facing tourism stakeholders is to appreciate that dealing sensibly with globalisation trends is not a byway on the road to responsible tourism management decisions, it is central to it. To cope with future tourism planning, management and research, tourism professionals will increasingly have to be Renaissance men and women, particularly in the Southern African context. The need to passionately imagine, perceive and gauge the future is paramount professional attributes of the tourism professionals of tomorrow.

\section{REFERENCES}

1 ADEJUWON, F. (1996) "Globalisation of Tourism and its Effects on Africa with Special Regard to Nigeria", in: Keller, P. (ed.), Globalisation and Tourism, AIEST, St. Gallen.

2 BULHALIS, D. \& COOPER, C. (1998) "Competition or Co-Operation? Small and Medium Sized Tourism Enterprises at the Destination", in Embracing and Managing Change in Tourism: International Case Studies, (eds.) Laws, E., Faulkner, B. and Moscardo, G. London: Routledge: 32446.

3 CLIFT, S. \& PAGE, S. (1996) Health and the International Tourist, London: Routledge.

4 COOK, R. YALE, L. \& MARQUA, J. (1999) Tourism: The Business of Travel, New Jersey: Prentice Hall,

5 COOPER, C., FLETCHER, J., GILBERT, D. \& WANHILL, S. (1999) Tourism Principles and Practices ( $2^{\text {nd }}$ ed.) New York: Longman.

6 D'AVENI, R. (1998) Hypercompetition Closes in, Financial Times.

7 GOELDNER, C.R., RITCHIE, J.R. \& MCINTOSH, R. (2000) Tourism: Pinciples, Practices and Philosophies, $\left(8^{\text {th }}\right.$ ed.) New York: John Wiley \& Sons.

8 GO, F. (1996) "A Conceptual Framework for Managing Global Tourism" Tourism Recreation Research, Vol. XXI, No. 2.

9 HALL, M. (2000) "The Future of Tourism: A Personal Speculation", Tourism Recreation Research, Vol. 25(1): 85-95.

10 HANNIFIN, J. \& LE QUESNE, N. (1998) "Flights of Fantasy", Time Asia, 151 (24) June 22.

11 HEATH, E. (2000) "Key Trends in Destination Marketing: Lessons from Global 'Best Practice' Destinations", in: Ruddy, J. and Flanagan, S. (eds.), Tourism Destinations: Gaining the Competitive Edge, Tourism Research Centre, Dublin Institute of Technology.

12 KELLER, P. (1996) Globalisation of Tourism, AIEST, St Gallen. 
13 MATAS, R. (1998) "South African at Meeting Backed by Ottowa", The Canadian Globe and Mail.

14 MCINTOSH, R., GOELDNER, C. \& RITCHIE, B. (1995) Tourism: Principles, Practices and Philosophies ( $7^{\text {th }}$ ed.) Canada: John Wiley and Sons.

15 MOUTINHO, L. (2000) Strategic Management in Tourism, New York: CABI Publishing.

16 NAISBITT, J. (1994) Global Paradox, New York: Wamer Books.

17 PAGE, S. BRUNT, P., BUSBY, G. \& CONNELL, J. (2001) Tourism: A Modern Synthesis, London: Thomson Learning.

18 PIZAM, A. \& MANSFELD, Y. (1996) Tourism, Crime and International Security Issues, Chichester: John Wiley and Sons.

19 POON, A. (1993) Tourism, Technology and Competitive. Strategies. Wallingford: International.

20 POPCORN, F. (1996) Clicking, Harper Collins: London.

21 SHELDON, P. (1997) Tourism Information Technology. Wallingford: CAB International.

22 SOUTHERN AFRICA'S TRAVEL NOW, 28 July 2000.

23 TRAVEL NOW, May 18, 2001,

24 VANHOVE, N. (1996) "Globalisation of Tourism Demand: The Underlying Factors and the Impact on Marketing Strategy", in: Keller, P. (ed.) Globalisation and Tourism, AIEST, St. Gallen.

25 VELLAS, F.A. \& BECHEREL, L. (1999) The International Marketing of Travel and Tourism: A Strategic Approach, London: Macmillan Press.

26 WOLFF, H. (1998) A Tour of the Future, Wimberly Allison Tong \& Goo, Finan Publishing.

27 WORLD TRAVEL AND TOURISM COUNCIL (1996) Progress and Priorities 1996, London: WTTC.

28 WORLD TOURISM ORGANISATION (1996) Tourism Highlights. Madrid: WTO.

29 WORLD TOURISM ORGANISATION (1998) “Governments' Role in Tourism", WTO News. September/October.

30 WORLD TOURISM ORGANISATION (1999) Tourism 2020 Vision, Madrid: WTO.

31 YOUELL, R. (1998) Tourism: An Introduction, Essex: Longman. 